\title{
PHYSICAL-MECHANICAL CHARACTERIZATION OF THE WOOD OF Plathymenia reticulata BENTH (VINEYARD-OF-FIELD) NATIVE SPECIES OF THE CERRADO OF THE STATE OF TOCANTINS
}

\author{
Raquel Marchesan ${ }^{1 *}$, Lucas Alves Ferreira Souza ${ }^{2}$, Rodrigo Araújo Fortes ${ }^{3}$, Raydel Lorenzo Reinaldo ${ }^{4}$, André \\ Orathes do Rego Barros ${ }^{5}$, André Ferreira dos Santos ${ }^{6}$

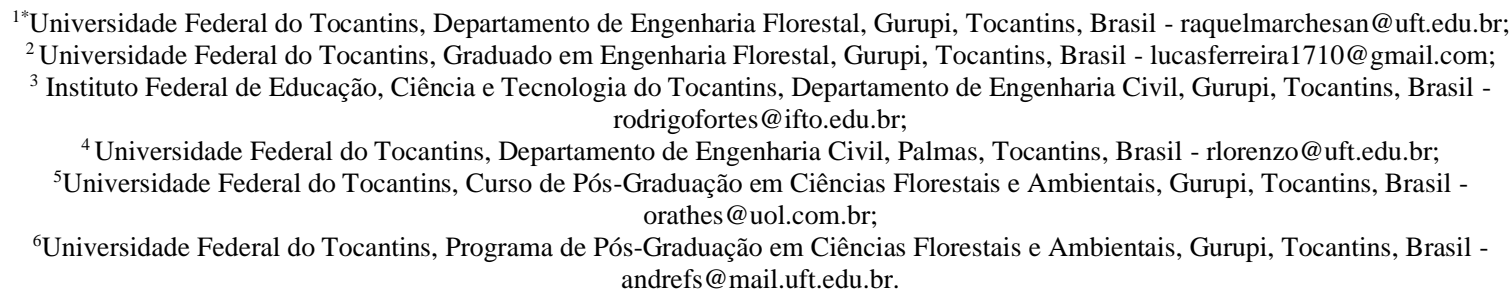

Received for publication: 18/08/2019 - Accepted for publication : 06/05/2020

\begin{abstract}
Resumo
Caracterização físico-mecânica da madeira de Plathymenia reticulata Benth (Vinhático-do-campo) espécie nativa do Cerrado do estado do Tocantins. O objetivo deste trabalho foi determinar as propriedades físicas e mecânicas da madeira de Plathymenia reticulata Benth (vinhático-do-campo), visando indicar suas potencialidades de uso para a construção civil. A madeira utilizada na produção dos corpos de prova é oriunda de floresta nativa do município de Dueré - TO. Foram obtidos a densidade básica, retratibilidade da madeira e o coeficiente de anisotropia nos ensaios físicos e os valores de resistência à compressão axial e flexão estática nos ensaios mecânicos. Os valores obtidos demonstraram que a madeira de Plathymenia reticulata Benth se enquadra na classificação de resistência C40 para madeiras de folhosas, determinada pela Norma Brasileira

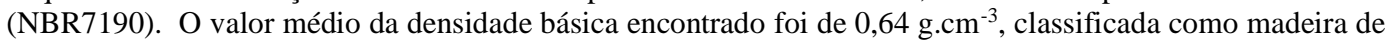
média densidade e os valores de retratibilidade tangencial, radial e volumétrico foram iguais a $6,11 \%, 3,06 \%$, $9,39 \%$, respectivamente. Quanto suas características mecânicas, presentou valores médios de resistência à compressão paralela às fibras, resistência à flexão estática e módulo de elasticidade iguais a 58,8MPa, 128,2 $\mathrm{MPa}$ e $12760,0 \mathrm{MPa}$, respectivamente. A madeira de vinhático-do-campo pode ser classificada como madeira estável e suas características físicas sugerem uma qualidade normal. A espécie pode ser aplicada na construção civil leve e pesada.

Palavras-chave: Estabilidade dimensional. Densidade básica. Qualidade da madeira. Resistência da madeira.
\end{abstract}

\begin{abstract}
The objective of this work was to determine the physical and mechanical properties of Plathymenia reticulata Benth (vinhático-do-campo) wood to indicate its potential use. The wood used in the production of the specimens came from the municipality of Dueré - TO native forest. The basic density, wood retractability, and anisotropy coefficient were obtained from physical tests, and the values of axial compression and static flexion resistance from the mechanical tests. The values obtained showed that the Plathymenia reticulata Benth wood fits the C40 resistance classification for hardwoods, determined by the Brazilian Standard (NBR7190). The average value of the basic density found was $0.64 \mathrm{~g} \mathrm{~cm}^{-3}$, classified as a medium density wood and the values of tangential, radial and volumetric retractability were $6.11 \%, 3.06 \%, 9.39 \%$, respectively. As for its mechanical characteristics, it presented average values of compressive strength parallel to the fibers, resistance to static flexion, and elastic modulus equal to $58.8 \mathrm{MPa}, 128.2 \mathrm{MPa}$, and $12760.0 \mathrm{MPa}$, respectively. The vinhático-do-campo wood can be classified as stable wood and its physical characteristics suggest a normal quality. The species can be applied in light and heavy construction.

Keywords: Dimensional stability. Basic density. Wood quality. Wood resistance.
\end{abstract}

\section{INTRODUCTION}

According to the Brazilian Forest Service (SFB) (2010), Brazil has one-third of the tropical forests in the world, standing out as one of the main producers of wood. Most of its territorial extension, approximately 516 million hectares ( $60.7 \%$ of its territory), is formed by natural and planted forests, which makes the country the second largest forest area in the world, only behind Russia.

The Cerrado is the second largest Brazilian biome in extension, with about 204 million hectares, occupying approximately $24 \%$ of the national territory, it plays a fundamental role in the process of distribution of water resources across the country (LIMA, 2011). The native species of the cerrado biome have multiple uses,

FLORESTA, Curitiba, PR, v. 51, n. 1, p. 247-254, jan/mar 2021.

Marchesan, R. et.al.

ISSN eletrônico 1982-4688

DOI: $10.5380 /$ rf.v51 i1. 68591 
for round wood, sawn wood, non-timber forest products, presenting great potential for anthropic use, as long as they are exploited sustainably.

Plathymenia reticulata Benth is among these species, belonging to the Leguminosae family, subfamily Caesalpinoideae, and popularly known as vinhático-do-campo, a native species of the cerrado biome (L.P.W.G., 2017).

The great variability of native forest species in Brazil means that many have not yet studied their characteristics (SILVA et al., 2014). Despite the great importance of knowledge of the properties of wood, little is known about most species, as is the case of the vineyard-of-the-field.

According to Bonduelle et al. (2015), the physical properties of the woods are among the most important, and their knowledge is essential because it is associated with the various forms of processing, as well as the various forms of use. Among the physical properties, the basic density is one of the main parameters of wood quality, as it influences the thermal, physical properties, and mechanical resistance of the wood. (GUIMARÃES JUNIOR $e t$ al., 2016)

Retractability is a property of wood that can limit its use and the need for specific processing techniques. The wood undergoes dimensional variation and the determination of the retraction coefficients of the wood is an important index in the evaluation of the dimensional variation (KOLLMANN; COTÊ, 1968).

Among the mechanical properties of the wood, the axial compression strength determines the wood's capacity to withstand forces by compressing the fibers, and flexural strength determines the elasticity modulus and the wood's capacity to withstand bending moment demands.

In this context, the objective of the work was to determine the physical and mechanical properties of the wood of Plathymenia reticulata Benth, aiming to indicate its potential for use in civil construction.

\section{MATERIAL AND METHODS}

Three trees were chosen at random, which had trunks with an average diameter of $70 \mathrm{~cm}$ at breast height $(\mathrm{DBH})$, taken at $1.30 \mathrm{~m}$ from the ground. The trees were unfolded in logs of 1.50 meters in length, in which the chainsaws, with chainsaw first removed for transformation into blocks, then they were transformed into planks to facilitate the unfolding in the joinery and finally the samples for transport, composed of elements from the base to the top, aiming at the homogenization of the samples, being identified and stored in plastic bags for later preparation of the specimens.

In order to determine the basic density and retractability of the wood, 10 oriented specimens with dimensions of $25 \mathrm{~mm} \times 25 \mathrm{~mm}$ x $50 \mathrm{~mm}$ (width x thickness $\times$ length) were made, based on the COPANT 461 standard (1972).

For the axial compression test, 10 specimens with dimensions of $50 \mathrm{~mm}$ x $50 \mathrm{~mm}$ x $150 \mathrm{~mm}$ (width $\mathrm{x}$ thickness x length) were produced, according to COPANT 464 (1972).

For the static bending test, 6 specimens with dimensions of $20 \mathrm{~mm}$ x $20 \mathrm{~mm}$ x $300 \mathrm{~mm}$ were produced, with a greater dimension in the direction of the fibers, based on the COPANT 555 standard (1973).

\section{Basic density}

In determining the basic density, the hydrostatic balance method was used, according to the ASTM D2395 (2005) standard. The specimens were saturated in a vacuum desiccator until constant weight. After saturation, the saturated volume of the specimens was determined. In order to determine the dry weight, the samples were dried in air and then taken to the oven at $103^{\circ} \mathrm{C} \pm 2{ }^{\circ} \mathrm{C}$ until they reached a constant weight. The dry specimens were weighed on an analytical balance to obtain the dry mass. Basic density was calculated using Equation 1.

$$
D B=\frac{P}{V}
$$

where: DB the basic density $\left(\mathrm{g} \mathrm{cm}^{-3}\right), \mathrm{P}$ the dry weight $(\mathrm{g})$, and $\mathrm{V}$ the saturated volume $\left(\mathrm{cm}^{3}\right)$.

\section{Retractability}

In order to determine the shrinkage coefficients; the specimens followed the same saturation and drying methodology used for the basic density. When saturated, the specimens were measured on the tangential, radial, and longitudinal faces, using a digital caliper. After drying in an oven at $0 \%$, measurements were again taken at the same points when saturated. The values of the tangential $\left(\mathrm{C}_{\mathrm{tn}}\right)$, radial $\left(\mathrm{C}_{\mathrm{rn}}\right)$, longitudinal $\left(\mathrm{C}_{\mathrm{ln}}\right)$, volumetric $\left(\mathrm{C}_{\mathrm{vn}}\right)$, and FA (anisotropic factor) coefficients were calculated using the following formulas:

FLORESTA, Curitiba, PR, v. 51, n. 1, p. 247-254, jan/mar 2021.

Marchesan, R. et.al.

ISSN eletrônico 1982-4688

DOI: 10.5380/rf.v51 i1. 68591 


$$
C_{(i) n}=\frac{d_{u(i)}-d_{s(i)}}{d_{u(i)}} * 100
$$

where: $\mathrm{C}_{(\mathrm{i}) \mathrm{n}}$ the retraction in the desired direction $(\%), \mathrm{d}_{\mathrm{u}(\mathrm{i})}$ the wet specimen dimension $(\mathrm{mm}) ; \mathrm{d}_{\mathrm{s}(\mathrm{i})}$ the dimension of the dry specimen $(\mathrm{mm})$; and $\mathrm{i}$ the direction considered: either radial, tangential or longitudinal;

$$
C_{v n}=C_{t n}+C_{r n}+C_{l n}
$$

where: $\mathrm{C}_{\mathrm{vn}}$ the volumetric retraction (\%), $\mathrm{C}_{\mathrm{tn}}$ the retraction in the tangential direction $(\%), \mathrm{C}_{\mathrm{rn}}$ the retraction in the radial direction (\%), and $\mathrm{C}_{\mathrm{ln}}$ the retraction in the longitudinal direction (\%).

$$
F A=\frac{C_{t n}}{C_{r n}}
$$

where: FA the anisotropic factor, $\mathrm{C}_{\mathrm{tn}}$ the retraction in the tangential direction (\%), and $\mathrm{C}_{\mathrm{rn}}$ the retraction in the radial direction $(\%)$.

\section{Determination of compressive strength parallel to fibers}

To determine the maximum axial compression stress, the specimens, with a moisture content of $12 \%$, were tested in a universal QUANTEQ machine with a force capacity of $3000 \mathrm{kN}$. The test was carried out at a constant speed of $0.6 \mathrm{~mm} / \mathrm{min}$ until the specimen ruptured. The compressive strength values parallel to the fibers were calculated using the following formula:

$$
f_{c 0}=\frac{F_{c 0, \max }}{A}
$$

where: $\mathrm{f}_{\mathrm{c} 0}$ the compressive strength parallels to the fibers (MPa), $\mathrm{F}_{\mathrm{c} 0 \text {, max }}$ the maximum compression force applied to the specimen $(\mathrm{N})$ and A the cross-sectional area $\left(\mathrm{mm}^{2}\right)$.

\section{Determination of the modulus of elasticity and resistance to static bending}

To determine the tensile strength and elastic modulus, mechanical tests of static bending were performed, with a moisture content of $12 \%$ and a constant deformation speed of $0.6 \mathrm{~mm} / \mathrm{min}$ until the specimen ruptured. The specimens were tested in a universal QUANTEQ machine with a force capacity of $3000 \mathrm{kN}$, using a static scheme of a supported isostatic beam with a central concentrated load. The values of conventional resistance $\left(\mathrm{f}_{\mathrm{M}}\right)$ and modulus of elasticity $\left(\mathrm{E}_{\mathrm{M}}\right)$ were given by the following formulas:

$$
f_{M}=\frac{6 P l}{4 b h^{2}}
$$

where: $\mathrm{f}_{\mathrm{M}}$ the conventional resistance to static bending (MPa), $\mathrm{P}$ the maximum applied load $(\mathrm{N}), l$ the distance between the supports in the static bending test $(\mathrm{mm}), \mathrm{b}$ the cross-section width of the specimen $(\mathrm{mm})$, and $\mathrm{h}$ the section height cross-section of the specimen $(\mathrm{mm})$.

$$
E_{M}=\frac{\left(F_{50 \%}-F_{10 \%}\right) l^{3}}{\left(V_{50 \%}-V_{10 \%}\right) 4 b h^{3}}
$$

where: $\mathrm{E}_{\mathrm{M}}$ the modulus of elasticity in static bending $(\mathrm{MPa}), \mathrm{F}_{50 \%}$ the force corresponding to $50 \%$ of the obtained force $(\mathrm{N}), \mathrm{F}_{10 \%}$ the force corresponding to $10 \%$ of the obtained force $(\mathrm{N}), l$ the distance between the supports in the static bending test $(\mathrm{mm}), \mathrm{V}_{50 \%}$ the arrow in the center of the span with $\mathrm{F}_{50 \%}(\mathrm{~mm}), \mathrm{V}_{10 \%}$ the arrow in the center of the span with $\mathrm{F}_{10 \%}(\mathrm{~mm}), \mathrm{b}$ the cross-section width of the specimen $(\mathrm{mm})$ and $\mathrm{h}$ the height of the cross-section of the specimen $(\mathrm{mm})$.

\section{Statistical analysis}

The statistical analysis performed for the data was descriptive. The calculated parameters were the arithmetic means, standard deviation, and the coefficient of variation, using the Excel® 2010 program. 


\section{RESULTS}

Table 1 shows the average values and coefficients of variation obtained for basic density, shrinkage, anisotropic factor, strength, and elasticity modulus of Plathymenia reticulata Benth wood.

Table 1. Physical and mechanical properties of wood Plathymenia reticulata Benth.

Tabela 1. Propriedades físico-mecânicas da madeira de Plathymenia reticulata Benth.

\begin{tabular}{lccc}
\hline \multicolumn{1}{c}{ Properties } & & Average & $\mathrm{CV}(\%)$ \\
\hline Basic Density & $\mathrm{DB}\left(\mathrm{g} \mathrm{cm}^{-3}\right)$ & 0.64 & 4.13 \\
Tangential Retraction & $\mathrm{C}_{\mathrm{tn}}(\%)$ & 6.11 & 10.86 \\
Radial Retraction & $\mathrm{C}_{\mathrm{rn}}(\%)$ & 3.06 & 21.53 \\
Longitudinal Retraction & $\mathrm{C}_{\mathrm{ln}}(\%)$ & 0.22 & 55.27 \\
Volumetric Retraction & $\mathrm{C}_{\mathrm{vn}}(\%)$ & 9.39 & 8.37 \\
Anisotropic Factor & $\mathrm{FA}(\%)$ & 2.00 & 18.06 \\
Compressive Strength & $f_{c 0}(\mathrm{MPa})$ & 58.81 & 13.41 \\
Static Flexural Strength & $f_{M}(\mathrm{MPa})$ & 128.20 & 11.68 \\
Modulus of elasticity & $E_{M}(\mathrm{MPa})$ & 12760.00 & 7.58 \\
\hline
\end{tabular}

MPa: megapascal; CV: coefficient of variation; \%: percentage; $\mathrm{g} \mathrm{cm}^{-3}$ : grams per cubic centimeter.

The coefficients of variation shown in Table 1 for basic density, tangential shrinkage, volumetric shrinkage, compressive strength, resistance to static bending, and elasticity module, indicated that the data are solid and there was little variation in the results found in the evaluated parameter. However, for the radial retraction and anisotropic factor, the coefficients of variation indicated average data dispersion, and for longitudinal retraction, there was a high dispersion of the data.

\section{DISCUSSION}

To indicate the potential for the use of Plathymenia reticulata Benth wood, 8 species were selected with 5 or more applications in the construction industry, for comparison purposes, indicated by the Institute for Technological Research (IPT). The average value of basic density found was $0.64 \mathrm{~g} \mathrm{~cm}-3$, classifying the studied wood as medium density wood, according to Melo, Coradin, and Mendes (1997). In a study by Machado Neto et al. (2015), the authors found for Plathymenia reticulata Benth the average value of basic density of $0.52 \mathrm{~g} \mathrm{~cm}-3$, showing to be lower than the average value found in the present work for the same species.

Table 2 shows the average values of the basic density of the wood of Plathymenia reticulata Benth compared to other species used in civil construction.

Table 2. Average values of basic density of Plathymenia reticulata wood in comparison with the species Hymenolobium petraeum, Cedrelinga cateniformis, Dipteryx odorata, Apuleia leiocarpa, Hymenaea courbaril, Astronium lecointei, Peltogyne spp, and Bagassa guianensis. wood.

Tabela 2. Valores médios de densidade básica da madeira de Plathymenia reticulata Benth em comparação com as espécies Hymenolobium petraeum, Cedrelinga cateniformis, Dipteryx odorata, Apuleia leiocarpa, Hymenaea courbaril, Astronium lecointei, Peltogyne spp e Bagassa guianensis.

\begin{tabular}{|c|c|}
\hline Species & DB $\left(\mathrm{g} \mathrm{cm}^{-3}\right)$ \\
\hline Plathymenia reticulata Benth (vinhático-do-campo) & 0.64 \\
\hline Hymenolobium petraeum (angelim-pedra) ${ }^{1}$ & 0.62 \\
\hline Cedrelinga cateniformis (cedrorana) ${ }^{2}$ & 0.47 \\
\hline Dipteryx odorata (cumaru) ${ }^{3}$ & 0.87 \\
\hline Apuleia leiocarpa $(\text { garapa })^{4}$ & 0.67 \\
\hline Hymenaea courbaril (jatobá) $)^{1}$ & 0.79 \\
\hline Astronium lecointei (muiracatiara) $)^{5}$ & 0.85 \\
\hline Peltogyne spp (pau-roxo) ${ }^{6}$ & 0.72 \\
\hline Bagassa guianensis (tatajuba) ${ }^{7}$ & 0.85 \\
\hline
\end{tabular}

DB: basic density; ${ }^{1}$ CASTRO et al. (2015); ${ }^{2}$ FERNANDES et al. (2018); ${ }^{3}$ ZAU et al. (2014); ${ }^{4}$ IPT (2013); ELEOTÉRIO e SILVA (2012); ${ }^{6}$ RIBEIRO et al., (2019); ${ }^{7}$ RIBEIRO et al., (2018).

FLORESTA, Curitiba, PR, v. 51, n. 1, p. 247-254, jan/mar 2021.

Marchesan, R. et.al.

ISSN eletrônico 1982-4688

DOI: $10.5380 /$ rf.v51 i1. 68591 
It can be seen that the value of basic density of the wood of Plathymenia reticulata Benth was close to that of the species Hymenolobium petraeum. It is also observed that the value of basic density of the wood of Plathymenia reticulata Benth was lower than that of the species Dipteryx odorata, Apuleia leiocarpa, Hymenaea courbaril, Astronium lecointei, Peltogyne spp, and Bagassa guianensis, respectively, being higher than that of the species Hymenolobium petraeum and Cedrelinga cateniformis, respectively.

Table 3 shows the mean values of retractability and the anisotropic factor of the species studied and other species used in civil construction.

Table 3. Average values of retractability and anisotropic factor for Plathymenia reticulate Benth wood in comparison with the species Hymenolobium petraeum, Cedrelinga cateniformis, Dipteryx odorata, Apuleia leiocarpa, Hymenaea courbaril, Astronium lecointei, Peltogyne spp, and Bagassa guianensis. wood.

Tabela 3. Valores médios de retratibilidade e fator anisotrópico para as madeiras de Plathymenia reticulata Benth em comparação com as espécies Hymenolobium petraeum, Cedrelinga cateniformis, Dipteryx odorata, Apuleia leiocarpa, Hymenaea courbaril, Astronium lecointei, Peltogyne spp e Bagassa guianensis.

\begin{tabular}{|c|c|c|c|c|}
\hline \multirow[t]{2}{*}{ Species } & \multicolumn{3}{|c|}{ Retractability (\%) } & \multirow{2}{*}{$\begin{array}{l}\text { Anisotropic } \\
\text { Factor }\end{array}$} \\
\hline & Radial & Tangential & Volumetric & \\
\hline $\begin{array}{l}\text { Plathymenia reticulata Benth } \\
\text { (vinhático-do-campo) }\end{array}$ & 3.06 & 6.11 & 9.39 & 2.00 \\
\hline $\begin{array}{l}\text { Hymenolobium petraeum (angelim- } \\
\text { pedra) })^{1}\end{array}$ & 4.10 & 6.30 & 10.10 & 1.54 \\
\hline $\begin{array}{l}\text { Cedrelinga cateniformis } \\
\text { (cedrorana) })^{1}\end{array}$ & 4.80 & 7.90 & 11.80 & 1.65 \\
\hline Dipteryx odorata (cumaru) ${ }^{1}$ & 5.30 & 8.20 & 13.60 & 1.55 \\
\hline Apuleia leiocarpa (garapa) ${ }^{1}$ & 4.40 & 8.50 & 14.00 & 1.93 \\
\hline Hymenaea courbaril (jatobá) ${ }^{1}$ & 3.10 & 7.20 & 10.70 & 2.32 \\
\hline Astronium lecointei (muiracatiara) ${ }^{1}$ & 3.30 & 6.30 & 11.20 & 1.91 \\
\hline Peltogyne spp (pau-roxo) ${ }^{1}$ & 3.50 & 6.50 & 10.70 & 1.86 \\
\hline Bagassa guianensis (tatajuba) ${ }^{1}$ & 5.50 & 7.10 & 11.40 & 1.29 \\
\hline
\end{tabular}

1IPT (2013).

From the values in Table 3, it can be seen that the coefficients of tangential, radial, and volumetric retraction of the wood of Plathymenia reticulata Benth were lower than those of all species compared, being close to that of the species Astronium lecointei and Peltogyne spp with average values coefficients: radial of 3.30 and 3.50 , tangential of 6.30 and 6.50 , volumetric of 11.20 and 10.70 , respectively.

The values found for Plathymenia reticulata Benth wood demonstrate that the wood is reasonably stable in relation to volumetric variation, but, in contrast, its high anisotropic factor shows that the wood presents dimensional instability. For Oliveira et al. (2010), the difference in retractability between the radial and tangential directions is one of the main causes of wood defects, which occur during the drying process and are generated by the manifestation of anisotropy, that the higher the probability of occurrence increases defects in the wood.

Motta et al. (2014) studying Cedro wood (Cedrela fissilis) found that the high anisotropic factor indicates greater propensities to cracking and warping during dimensional changes, caused by dimensional variation during the drying process, being, therefore, more unstable. When analyzing the anisotropic factor of the wood of Plathymenia reticulata Benth, it is classified as low-quality wood, being close to the species Apuleia leiocarpa and Astronium lecointei with values of 1.93 and 1.91, respectively, and below the species Hymenaea courbaril with a value of 2.32. Due to the usage characteristics defined by IPT (2013) and those found for vinhático-docampo wood, its use in structures and frames is indicated, after due drying and treatment.

Table 4 presents the values of resistance to axial compression of the species studied and of other species used in civil construction.

Table 4. Average values of compressive stress of Plathymenia reticulata Benth woods in comparison with Hymenolobium petraeum, Cedrelinga cateniformis, Dipteryx odorata, Apuleia leiocarpa, Hymenaea courbaril, Astronium lecointei, Peltogyne spp, and Bagassa guianensis species.

Tabela 4. Valores médios de tensão de compressão axial das madeiras de Plathymenia reticulata Benth em comparação com as espécies Hymenolobium petraeum, Cedrelinga cateniformis, Dipteryx odorata, Apuleia leiocarpa, Hymenaea courbaril, Astronium lecointei, Peltogyne spp e Bagassa guianensis.

FLORESTA, Curitiba, PR, v. 51, n. 1, p. 247-254, jan/mar 2021.

Marchesan, R. et.al.

ISSN eletrônico 1982-4688

DOI: 10.5380/rf.v51 i1. 68591 


\begin{tabular}{|c|c|}
\hline Species & Compressive strength (MPa) \\
\hline Plathymenia reticulata Benth (vinhático-do-campo) & 58.8 \\
\hline Hymenolobium petraeum (angelim-pedra) ${ }^{1}$ & 52.3 \\
\hline Cedrelinga cateniformis (cedrorana) ${ }^{\mathbf{1}}$ & 46.6 \\
\hline Dipteryx odorata (cumaru) ${ }^{\mathbf{1}}$ & 92.2 \\
\hline Apuleia leiocarpa (garapa) ${ }^{1}$ & 54.3 \\
\hline Hymenaea courbaril (jatobá) ${ }^{1}$ & 82.2 \\
\hline Astronium lecointei (muiracatiara) ${ }^{1}$ & 51.3 \\
\hline Peltogyne spp (pau-roxo) ${ }^{1}$ & 81.1 \\
\hline Bagassa guianensis (tatajuba) ${ }^{1}$ & 79.7 \\
\hline
\end{tabular}

MPa: megapascal. ${ }^{1}$ IPT (2013).

When analyzing the resistance to axial compression, it appears that the woods of Plathymenia reticulata Benth, Hymenolobium petraeum, Apuleia leiocarpa, and Astronium lecointei fall under the C40 resistance classification for hardwoods, determined by NBR 7190 (1997). It is observed that the similarity of resistance to axial compression for the species Plathymenia reticulata Benth, Hymenolobium petraeum, and Apuleia leiocarpa is related to the values of basic densities.

When comparing the values of resistance to axial compression of all species (Table 4), it appears that the wood of Plathymenia reticulata Benth presents a median value, among those presented. The NBR 7190 (1997) indicates classes from $\mathrm{C} 20$ for use in civil construction, this result for the species studied, indicates the potential for structural use of wood.

Table 5 presents the average values of static flexural strength $\left(f_{m}\right)$ and the modulus of elasticity $\left(E_{\mathrm{w}}\right)$ of the species studied and of other species used in civil construction.

Table 5. Mean values of static flexural strength and modulus of elasticity of Plathymenia reticulata Benth woods in comparison with Hymenolobium petraeum, Cedrelinga cateniformis, Dipteryx odorata, Apuleia leiocarpa, Hymenaea courbaril, Astronium lecointei, Peltogyne spp, and Bagassa guianensis species.

Tabela 5. Valores médios de resistência à flexão estática e módulo de elasticidade da madeira de Plathymenia reticulata Benth em comparação com as madeiras das espécies Hymenolobium petraeum, Cedrelinga cateniformis, Dipteryx odorata, Apuleia leiocarpa, Hymenaea courbaril, Astronium lecointei, Peltogyne spp e Bagassa guianensis.

\begin{tabular}{|c|c|c|}
\hline Species & $\begin{array}{l}\text { Static Flexural Strength } \\
(\mathrm{MPa})\end{array}$ & Elasticity Module (MPa) \\
\hline $\begin{array}{l}\text { Plathymenia reticulata Benth (vinhático-do- } \\
\text { campo) }\end{array}$ & 128.2 & 12760.0 \\
\hline Hymenolobium petraeum (angelim-pedra) ${ }^{1}$ & 109.3 & 11572.0 \\
\hline Cedrelinga cateniformis (cedrorana) ${ }^{1}$ & 77.8 & 12847.0 \\
\hline Dipteryx odorata (cumaru) ${ }^{1}$ & 178.3 & 18547.0 \\
\hline Apuleia leiocarpa (garapa) ${ }^{1}$ & 125.3 & 14107.0 \\
\hline Hymenaea courbaril (jatobá) ${ }^{1}$ & 151.8 & 14837.0 \\
\hline Astronium lecointei (muiracatiara) ${ }^{1}$ & 101.6 & 12303.0 \\
\hline Peltogyne spp (pau-roxo) ${ }^{1}$ & 184.5 & 17721.0 \\
\hline Bagassa guianensis (tatajuba) ${ }^{1}$ & 138.2 & 15857.0 \\
\hline
\end{tabular}

MPa: megapascal. ${ }^{1}$ IPT (2013).

When analyzing the values of resistance to static bending exposed in Table 5, it was found that the species studied has a value close to Apuleia leiocarpa and a modulus of elasticity. As for the elasticity module, it was found that the studied species presents stiffness close to that of the species Cedrelinga cateniformis and Astronium lecointei. Due to its moderate resistance to flexion and stiffness, Plathymenia reticulata Benth wood meets the criteria for use in light and heavy construction, presented by IPT (2013).

FLORESTA, Curitiba, PR, v. 51, n. 1, p. 247-254, jan/mar 2021.

Marchesan, R. et.al.

ISSN eletrônico 1982-4688

DOI: $10.5380 /$ rf.v51 i1. 68591 


\section{CONCLUSIONS}

Given the above, it is concluded that:

- Plathymenia recticulata Benth wood was characterized as medium basic density wood, classified in the C40 resistance classification, with a lower volumetric shrinkage coefficient than that of the compared species, indicating less total dimensional variation.

- Although the values of the anisotropic factor present a high dispersion of the data, this result does not directly affect the potential use of Plathymenia recticulata Benth wood, and care must be taken in the drying and treatment of sawn wood.

- In this context, Plathymenia reticulata Benth wood has similar characteristics to the Apuleia leiocarpa species and can replace it.

\section{REFERENCES}

AMERICAN SOCIETY FOR TESTING AND MATERIALS. ASTM D-2395: standard test methods for specific gravity of wood and wood-based materials. Philadelphia, p. 8, 2005.

ASSOCIAÇÃO BRASILEIRA DE NORMAS TÉCNICAS. NBR 7190: Projetos de estruturas de madeira. Rio de Janeiro, 1997.

BONDUELLE, G. M.; IWAKIRI, S.; TRIANOSKI, R.; PRATA, J. G.; ROCHA, V. Y. Análise da massa específica e da retratibilidade da madeira de Tectona grandis nos sentidos axial e radial do tronco. Floresta, Curitiba, v. 45, n. 4, p. 671 - 680, 2015.

CASTRO, J. P; PERÍGOLO, D. M.; BIANCHI, M. L.; MORI, F. A.; FONSECA, A. de S.; ALVES, I. C. N.; VASCONCELLOS, F. J. de. Uso de espécies amazónicas para envelhecimento de bebidas destiladas: análises físicas e química da madeira. Cerne, Lavras, vol.21, n.2, p. 319 - 327, 2015.

COMISSION PANAMERICANA DE NORMAS TECNICAS. COPANT 461: Metodo de determinación del peso especifico aparente. Caracas, 1972.

COMISSION PANAMERICANA DE NORMAS TECNICAS. COPANT 464: Maderas: método de determinación de la compresión axil o paralela al grano. Caracas, 1972.

COMISSION PANAMERICANA DE NORMAS TECNICAS. COPANT 555: Maderas: método de ensayo de flexión estática. Caracas, 1973.

ELEOTÉRIO, J. R.; SILVA, C. M. K. Comparação de programas de secagem para Cumaru (Dipteryx odorata), Jatobá (Hymenaea spp) e Muiracatiara (Astronium lecointei) obtidos por diferentes métodos. Scientia Forestalis, v. 40, n. 96, p.537-545, dez. 2012.

FERNANDES, N. C. L.; VALLE, M. L. A.; CALDERON, C. M. A. Características físicas e anatômicas de Cedrela odorata L. e Cedrelinga cateniformis Ducke. Floresta e Ambiente. Rio de Janeiro. vol.25, n.1, e00100814. Epub Dec 11, 2018.

GUIMARÃES JUNIOR, J. B.; CANGUSSU, J. T.; LISBOA, F. J. N.; GUIMARÃES, I. L. Caracterização tecnológica da madeira de Myracrodruon urundeuva em diferentes classes diamétricas. Biosfera, Goiânia, v. 13, n.24; p. 250-261, 2016.

IPT - Instituto de Pesquisas Tecnológicas do Estado de São Paulo. Catálogo de Madeiras brasileiras para a construção civil. São Paulo, 2013. 103 p.

KOLLMANN, F. F. P.; COTÊ, W. A. Principles of wood science and technology. Berlin: Springer-Verlag, 1968. v. 1,592 p.

LIMA J. E. F. W. Situação e perspectivas sobre a água do Cerrado. Ciência e Cultura. Vol 63. No 3. São Paulo. Jun.2011.

L.P.W.G. A new subfamily classification of the Leguminosae based on a taxonomically comprehensive phylogeny The Legume Phylogeny Working Group (LPWG). Taxon, v. 66, n. 1, p. 44-77, 2017.

MACHADO NETO, A.P.; BRANDÃO, C.F.L. Densidade e poder calorífico como base para prevenção de incêndios florestais sob linhas de transmissão. Nativa, Sinop, v. 03, n. 01, p. 09-15, 2015.

FLORESTA, Curitiba, PR, v. 51, n. 1, p. 247-254, jan/mar 2021.

Marchesan, R. et.al.

ISSN eletrônico 1982-4688

DOI: $10.5380 /$ rf.v51 i1. 68591 
MELO, J. E.; CORADIN, V. T. R.; MENDES, J. C. Madeiras da Amazônia: Características e Utilização. Vol. 3 - Amazônia Oriental, Laboratório de Produtos Florestais, IBAMA, 1997. 141 p.

MOTTA, J. P.; OliVEIRA, J. T. da S.; BRAZ, R. L.; DUARTE, A. P. C.; ALVES, R. C. Caracterização da madeira de quatro espécies florestais. Ciência Rural, v. 44, n. 12, 2014.

OLIVEIRA, J. T. S.; TOMAZELLO FILHO, M.; FIEDLER, N. C. Avaliação da retratibilidade da madeira de sete espécies de Eucalyptus. Revista Árvore, Viçosa, v. 34, n. 5, p. 929-936, 2010.

RIBEIRO, D. S.; GONÇALVES, A. L.; MELO, C. F.; REIS, A. R. S. Reação da densidade e das propriedades mecânicas de três espécies amazônicas submetidas a ensaio de campo. Ciência da Madeira, v. 10, n. 1, p. 18-28, 2018.

RIBEIRO, E. S.; VARGAS, L. E. P.; PAULA, M. H.; CAMPOS, A. N. Propriedades tecnológicas da espécie Peltogyne confertiflora (Mart. ex Hayne) Benth. Biodiversidade, v.18, nº1, 2019.

SFB - Serviço Florestal Brasileiro. Florestas do Brasil em resumo - 2010: dados de 2005-2010. Brasília: DF, 2010. 152 p.

SILVA, D. A. et al. Avaliação das propriedades energéticas de resíduos de madeiras tropicais com uso da espectroscopia NIR. Revista Floresta e Ambiente, v. 21, n4, p. 561-568, 2014.

ZAU, M. D. L.; VASCONCELOS, R. P. de; GIACON, V. M.; LAHR, F. A. R. Avaliação das propriedades química, física e mecânica de painéis aglomerados produzidos com resíduo de madeira da Amazônica - Cumaru (Dipteryx Odorata) e resina poliuretana à base de óleo de mamona. Polímeros, São Carlos, v. 24, n. 6, p. 726-732, dez. 2014. 